Anđela ĐUKANOVIĆ, PhD*

Research Fellow

Institute for Criminological and

Sociological Research
Review Paper

Received: 26 July 2021

Accepted: 10 October 2021

UDK: 349:602.72(497.11)

608.1:[575:612.6.05

https://doi.org/10.47152/rkkp.59.3.2

\title{
REGULATION OF REPRODUCTIVE CLONING AND INHERITABLE GENETIC MODIFICATIONS ON HUMANS - PERILS AND DEFICIENCIES
}

Harms arising from reproductive cloning or inheritable genetic modifications, for the time being, seem significant. This is supported by the simple fact that the first cloned monkeys were short-lived or by the fact that inheritable genetic modifications still carry a high chance of getting "off-target" results, which could result in serious health problems. Inheritable genetic modifications, in particular, have a high therapeutic potential, and it is suggested that this technology's comprehension is shifting from an absolute ban, to concerns over safety issues. International law can prove to be facilitative when it comes to deciding which new technology should be prohibited, restricted or allowed, having in mind possible consequences and the so-called phenomenon of reproductive tourism. Legally binding regulation of both technologies has proven challenging at the universal level. However, there has been some progress in Europe on that matter. Harms arising from inheritable genetic modifications seem even higher than in the case of reproductive cloning, since they have the potential to affect the whole of humanity, including future generations. The Criminal Code of Serbia and the Constitution of the Republic of Serbia prohibit reproductive cloning. However, the prohibition of inheritable genetic modifications on humans is

E-mail: andjelasto@sbb.r 
not regulated explicitly in the Criminal Code of Serbia, making this technology seem more acceptable or less harmful.

\section{Keywords: inheritable genetic modifications, reproductive cloning, gene editing, human rights, criminal law.}

\section{Introduction}

The issue of dangers or harms to society arising from reproductive cloning intensified after Dolly the sheep was cloned in 1996. This caused a sudden increase in the subject's importance, especially in relation to the possibility of the first human clone creation. In the years surrounding this event, many states introduced laws that regulate reproductive cloning of humans, although the possibility of the creation of a human clone in practice still seemed distant. The issue of reproductive cloning of human beings became interesting again after Chinese researchers reported in 2018 that they had successfully cloned macaque monkeys using the same technique used for the creation of Dolly the sheep, the technique of somatic cell nuclear transfer https://en.wikipedia.org/wiki/Somatic_cell_nuclear_transfer-SCNT (Zhen L. et al., 2018). This is significant because it is the first time that non-human primates have been cloned successfully, making the possibility of human clone creation much closer in practice.

On the other hand, the application possibilities and usefulness of this technique suggest that reproductive cloning does not offer much in this sense, unlike therapeutic cloning, which is considered ethically much more acceptable and can have significant therapeutic functions. Genetic modifications on humans in general also seem more promising in relation to therapeutic functions and could represent a cure for a large variety of diseases. Genome editing tools that are now available, like clustered regularly interspaced short palindromic repeats (CRISPR), zinc-finger nucleases (ZFN), transcription activator-like effector nucleases (TALEN), mitochondrial replacement techniques (MRT) in the case of mitochondrial diseases, seem more promising and more applicable. This is also the case with non-therapeutic functions. For example, the creation of soldiers with a combination of desired traits at a low cost certainly seems attractive. The opportunities that genetic modifications can offer, as well as the social harms resulting from modifications of the genome of descendants, might even seem higher than the reproductive cloning of human beings. In addition, it seems that genetic engineering home lab kits are available online, and some so-called biohacking celebrities are even performing live "CRISPR stunts" on themselves, on social networks or blogs, like, for example, an attempt to genetically engineer skin colour (Sigal, 
2019). This was not an isolated incident, and the United States Food and Drug Administration did release a notice stating the sale of DIY gene-editing kits for use on humans is against the law. ${ }^{1}$ However, it might still be possible to purchase them online, if they originate from a country that does not regulate or has less strict norms on this issue. Luckily, this version of CRISPR does not produce modifications that could be passed down to future generations, but they do offer valuable insight into the human relationship with genetic modifications as a tool for human enhancement, for curing diseases, or even for easy publicity. They also provide us with the realisation that experimentation of this kind can easily shift from laboratories.

Reproductive cloning implies replication of gene sets so that the clone and the source of material are in a situation that is comparable to identical twins (except for the age difference). The practical significance of human cloning is not as promising as in the case of genetic modifications. However, there is a possibility of using reproductive cloning to resolve infertility, making it possible for some couples or individuals even to have a child to which they are biologically related. However, this is not a simple method for resolving infertility, but also a method for influencing the characteristics of the future child, and therefore, no longer related to therapeutic effects only (Mujović-Zornić, 2007: 62). Reproductive cloning could also be combined with genetic modification to create a child that is genetically related to both parents (Strong, 2005).

Inheritable genetic modifications are also still in the experimental phase in animals. At the moment, they are not safe or effective, and significant technical and epistemic hurdles must be resolved before large-scale human genetic engineering (Powell, 2015: 670). Recent claims about inheritable genetic modifications in humans, through the CRISPR technique, have stirred the scientific public. After Chinese scientists' claim of successfully changing twin embryos so that they have immunity to HIV, scientists are calling for a global moratorium on editing human genes that can be passed down to generations (Kuchler, 2019). However, it has been reported that the scientist who created the world's first known genetically modified babies was sentenced to three years in prison and fined 3 million yuan. It seems that the doctors unknowingly used the gene-edited embryos through assisted reproductive technology, and two persons gave birth to three gene-edited babies as a result of the procedure. The domestic court found that his behavior constituted a criminal offence of illegal medical practice (Xinhuanet, 2019).

1 United States Food and Drug Administration, Information About Self-Administration of Gene Therapy, 11/21/2017, available at: https://www.fda.gov/vaccines-blood-biologics/cellular-genetherapy-products/information-about-self-administration-gene-therapy 
An argument usually used against inheritable genetic modifications is the possibility of creating unwanted genetic changes or other unforeseen consequences in future generations. The ultimate fear is related to the possibility of "intentional modification of the human genome so as to produce individuals or entire groups endowed with particular characteristics and required qualities". ${ }^{2}$ However, commonly, inheritable genetic modifications are justified by the possibility of curing diseases and not as a tool for human enhancement. This is not an advisable solution since there is a high chance of getting "off-target" results. Such 'off-target' cuts could result in serious health problems. For example, a change to a gene that suppresses tumour growth might lead to cancer, or sometimes genes differ among the cells of an individual, and this condition, known as mosaicism, also creates problems for gene editing (Ledford, 2019). However, the debate is slowly shifting from the absolute ban of inheritable genetic modifications on humans to the regulation of gene editing and the question of safety. ${ }^{3}$ When the inheritable genetic modifications on humans are deemed to be safe enough, the ban should be lifted, however, the most difficult issue is how to define the term "therapeutic" when deciding on allowing safe inheritable genetic modification, and how much (and which) of the "off-target" effects are acceptable, or where the difference between enhancement and therapy is (Beers, 2020:23-24). In addition, human error is always a factor, especially in the initial safety assessment. In this case, errors can have significant effects on the human species. It should be noted that, for most diseases, pre-implantation genetic diagnosis (PGD) offers the possibility of reproduction without passing a genetic disorder (Beers, 2020:24).

As a sufficient argument against inheritable genetic modifications on humans, the case of genetically modified food, perhaps, can also serve as an example of a technology that has been in broad use since the 1990s, but still with unclear adverse consequences and the great controversy surrounding this issue (Đukanović, 2019:14). This is even more evident in the case of inheritable genetic modification techniques on humans, which are currently underdeveloped, much more complex, and could directly affect humans and alter humanity's future in unforeseen ways. Nevertheless, despite the controversy surrounding genetically modified food, after decades of consumption, genetically modified animals are certainly becoming a reality.

2 Explanatory Report to the Convention for the Protection of Human Rights and Dignity of the Human Being with regard to the Application of Biology and Medicine: Convention on Human Rights and Biomedicine - Explanatory Report to the Convention on Human Rights and Biomedicine. Oviedo, 4.IV.1997, European Treaty Series - No. 164, par. 89.

3 Recommendation 2115 (2017) The use of new genetic technologies in human beings, Council of Europe, adopted by the Assembly on 12 October 2017 (35th Sitting), par 2. 
The use of Mitochondrial replacement technique (MRT) in the case of Mitochondrial disease is also controversial, especially because the popular phrase "three-parent baby" is used to describe the procedure. MRT implies in vitro fertilization in which some or the entire future child's mitochondrial DNA derives from a third person. The first baby was born using this technique in Mexico in 2016, but the mother's eggs contained faulty mitochondria, which could lead to very serious diseases (Ghose, 2016). However, by using this technique in order to resolve fertility problems related to poor egg quality (the mother did not have mitochondrial problems), the first child was born in Greece in 2019 (Thomson, 2019). Involved and still unknown risks are certainly more justified in the case of Mitochondrial disease than in the case of poor egg quality, since other, safer techniques are available in this case. Only the United Kingdom explicitly allows MRT. However, it has already been used in countries that do not explicitly legalize it but which have more relaxed laws on genetic modification, like Mexico, Ukraine, and Greece (Ong, 2018). In relation to this issue, it is important to state that currently there is no consensus among scientists on the question of whether this technique represents germline gene modification or it belongs to a slightly different category, like "conditionally inheritable genomic modification" (Newson and Wrigley, 2017: 66-67). Regardless of the accepted categorization, it must be noted that MRT does give significantly less control over an embryo's genes than, for example, the CRISPR technique, because the mitochondria contain only about 0.1 percent of a person's DNA (Viswanathan, 2018). Still, it is too early for reliable data on the long-term safety of this technique, and in the case of the birth of females, genetic modifications are passed to their offspring.

It can be concluded that germline manipulations and unexpected genetic mutations have an irreversible effect on all descendants, while reproductive cloning represents an less intrusive intervention into the genetic heritage of humanity, since the genetic make-up of the cloned offspring would be transmitted from almost exclusively one person (Navratyil, 2013:113).

It must be noted that the issue of reproductive cloning has almost been deserted in literature dealing with ethical and legal dilemmas surrounding the issue in the last fifteen years, after its initial popularity. On the other hand, gene engineering, genetic modification, gene editing (especially in relation to the CRISPR technique), as well as therapeutic cloning or stem cell research, seem very topical.

The issue of the artificial creation of chimeras and hybrids is also thematically related to the issue of reproductive cloning and genetic modifications, although there is still no official reported birth of such organisms. Human-animal hybrids or chimera embryos have been made but never brought to term. This is 
also a potentially therapeutically applicable procedure for producing animals with organs made from human cells that could be transplanted.

\section{The notion of reproductive cloning and inheritable genetic modifications}

Reproductive cloning can be defined as the deliberate production of genetically identical individuals. Clones contain identical sets of genetic material in the nucleus (that contains the chromosomes) of every cell in their bodies. Thus, cells from two clones have the same DNA and the same genes in their nuclei (National Research Council, 2002: 24). Therefore, reproductive cloning is a method used to make a clone or an identical copy of an entire organism. Reproductive cloning is also a form of artificial human reproduction. On the other hand, nonreproductive cloning implies the cloning of cells and tissues or the use of embryonic cells in cloning techniques. These two situations do not imply the creation of an entire organism and can have significant therapeutic functions. The two recognized methods used for reproductive cloning are cloning using somatic cell nuclear transfer (SCNT) and cloning by embryo splitting. It must be noted that the SCNT technique does not create "genetically identical" humans, which is a formulation used in many statutes or international instruments, since the embryo created via SCNT is not totally genetically identical to the ancestor because of the very low mitochondrial DNA remaining in the cytoplasm of the enucleated egg (Navratyil, 2013:109).

When it comes to genetic modifications of humans, it must be noted that different terms are widely used. Germline genetic modification changes the genes in eggs, sperm, or early embryos, and it is also referred to as "inheritable genetic modification" or "gene editing for reproduction". These alterations would appear in every cell of the person who developed from that gamete or embryo, and in all subsequent generations (Center for Genetics and Society). Somatic cell gene therapy aims to treat a disorder only in the diseased person, and not in their descendants. This is a method of introducing nucleic acids (RNA or DNA) into somatic cells (gene transfer) in order to change their genetic material and primarily treat genetically caused diseases, and sometimes even the treatment of diseases acquired during life, such as cancer and infectious diseases (German Reference Centre for Ethics in the Life Sciences, 2019). Therefore, it offers significant therapeutic functions without causing consequences which could be passed down to future generations. There are currently a number of techniques available for achieving human genetic modifications in general. 
However, it seems that the term genetic modification is being abandoned in favour of the term of gene editing. It is stated that it represents a more inclusive term. It involves the modification of the genome through targeted adding, replacing, or removing one or more DNA base pairs in the genome, regardless of whether the modifications occur in a particular gene or a non-coding region of the genome, and involves more precise, novel techniques (European Group on Ethics in Science and New Technologies, 2021: 12). In the United States, genetic engineering is widely accepted (European Group on Ethics in Science and New Technologies, 2021: 13). In EU regulations, the term genetic modification is still used. ${ }^{4}$

For the purpose of this work, we will use the term inheritable genetic modification, but with the realisation that different terms are in use. However, legal definitions of both reproductive cloning and inheritable genetic modifications must be determined by the result since there is always a possibility of developing novel techniques for achieving the same goal. This is the case especially in relation to inheritable genetic modification, since it is anticipated that existing genome editing techniques will continue to develop and that new techniques will emerge (Nuffield Council on Bioethics, 2016:4).

In addition, human-animal hybrids and chimeras are also related to human reproductive cloning and inheritable genetic modifications since they also involve the use of biotechnology in ethically sensitive issues. Hybrids result from the fusion of an egg and a sperm of different species into a single zygote from which all other cells of the hybrid organism originate, while in chimeras, the mixture takes place at the cell level, resulting in an organism whose cells keep their disparate genetic identity (Huther, 2009: 4).

\section{Reproductive cloning and inheritable genetic modifications in international instruments}

A general, legally binding provision of international human rights law that could be relevant in the case of reproductive cloning or genetic modifications could be found in Article 7 of the International Covenant on Civil and Political Rights (ICCPR). ${ }^{5}$ The provision is directed at the prohibition of torture and other

4 Directive 2001/18/EC of the European Parliament and of the Council of 12 March 2001 on the deliberate release into the environment of genetically modified organisms and repealing Council Directive 90/220/EEC - Commission Declaration, Official Journal L 106 , 17/04/2001 P. 0001 0039, Article 2:

5 International Covenant on Civil and Political Rights, UN General Assembly, 16 December 1966, United Nations, Treaty Series, vol. 999, p. 171. 
cruel, inhuman, and degrading treatment or punishment. However, it contains a unique sentence that is aimed directly at experiments on human beings: "In particular, no one shall be subjected without his or her free consent to medical or scientific experimentation" (Article 7 of the ICCPR). There is no doubt that free consent represents the basis of medical law in modern societies, and that experiments on humans without the free consent of the person in question do represent a violation of the prohibition of cruel, inhuman, or degrading treatment or punishment. This sentence was included in order to draw attention to this issue and prevent the recurrence of atrocities committed in concentration camps during the Second World War. ${ }^{6}$ However, this provision is not directed at experiments where free consent was obtained.

At the international level, the possibility of reaching a consensus is of particular importance in relation to new technologies. The dangers of the lack of regulation of controversial technologies are significant. States and international organisations must unite and participate in the debate about what technologies should be prohibited, restricted or allowed since the consequences could affect the entire human species. In addition, a well-known phenomenon is the so-called reproductive tourism, which mostly refers to individuals traveling to countries with more permissive laws in relation to in vitro fertilization. For example, sex selection for non-medical reasons is in most European countries forbidden, but in the US it is a legal possibility. It is not impossible to imagine offering the choice of desired traits of the future child in some jurisdictions. After all, this is a financially lucrative industry, which supports the possibility of other forms of selection in the future. Cloning might be commercially attractive to those who wish to have a clone of a decided person or a replica of themselves in case of infertility issues.

The UN failed to adopt a legally binding document directed at the issue of reproductive cloning. The Universal Declaration on the Human Genome and Human Rights, adopted by UNESCO in 1997, prohibits practices that are contrary to human dignity, such as reproductive cloning of human beings. ${ }^{7}$ The UN recognized the need to adopt a legally binding document devoted to the prohibition of reproductive cloning. However, in 2005, the legally non-binding Declaration on Human Cloning was adopted, with an even more vague provision on reproductive cloning. States are called to adopt the necessary measures to adequately protect human life, to prohibit all forms of human cloning inasmuch as they are incompatible

6 Annotations on the text of the draft International Covenants on Human Rights, U.N. Doc. A/2929 (1955), Agenda item 28 (Part II) Annexes, United Nations General Assembly Official Records, New York, 1955.

7 Universal Declaration on the Human Genome and Human Rights, UNESCO's 29th General Conference, 11 November 1997, Article 11. 
with human dignity and the protection of human life, and to "adopt the measures necessary to prohibit the application of genetic engineering techniques that may be contrary to human dignity" ${ }^{8}$ Therefore, the Declaration on Human Cloning ambiguous wording did not explicitly prohibit either reproductive or therapeutic cloning due to a lack of consensus on the introduction of the absolute prohibition of cloning or just the prohibition of reproductive cloning (Clados, 2012: pp. 90-91). States inclined to an absolute ban on cloning (including therapeutic cloning) could interpret the Declaration on Human Cloning as if it bans all forms of cloning, while states that are inclined to the prohibition of reproductive cloning could find that the prohibition is directed only at this cloning technique, which is "incompatible with human dignity and the protection of human life". In the latter case, for example, the United Kingdom permitted the technique of therapeutic cloning, believing that it offered the hope of new treatments, and therefore protection of human life and human dignity (Arsanjani, 2006:176). Theoretically, if some state is interested in allowing reproductive cloning, it can even find some creative arguments in favour of reproductive cloning being compatible with human dignity and the protection of human life. This is, above all, a result of the ambiguous term of "human dignity", usually used as a common bridge for achieving consensus in international instruments dealing with biomedicine matters. This would not be an issue if the Declaration on Human Cloning addressed relevant definitions adequately, like the term human cloning. The Declaration on Human Cloning's biggest success lies only in drawing attention to the issue of human cloning and the need for regulation, whatever the content of this regulation may be. Based on moral and ethical concerns, the United Nations should adopt a binding document that prohibits all forms of reproductive cloning and includes guidelines for states choosing to allow therapeutic cloning (Jarrel, 2006: 229). The Declaration on Human Cloning also addresses genetic engineering, although its title does not suggest so. Of course, the definition of genetic engineering is not present in the Declaration on Human Cloning, therefore it is not clear whether genetic engineering is contrary to human dignity in all cases, or just in the case of inheritable genetic modifications. Surprisingly, this issue did not attract the same attention as human cloning. Another attempt to reach universal consensus on genetic modifications is present in the Universal Declaration on the Human Genome and Human Rights. Article 5 a) of the Universal Declaration on the Human Genome and Human Rights states that "research, treatment or diagnosis affecting an individual's genome shall be undertaken only after rigorous and prior assessment

8 United Nations Declaration on Human Cloning, United Nations, A/RES/59/280, 23 March 2005. Point a-c. 
of the potential risks and benefits pertaining thereto and in accordance with any other requirement of national law". Therefore, there is no prohibition of inheritable genetic modifications, just the obligation of rigorous prior assessment of risks and benefits in relation to research, treatment, or diagnosis affecting an individual's genome.

At the regional level, the most relevant document is the 1997 Council of Europe Convention on Human Rights and Biomedicine (hereinafter: the Biomedicine Convention). ${ }^{9}$ The Biomedicine Convention is legally binding. Currently, 29 Council of Europe member states have ratified the Biomedicine Convention, and the Republic of Serbia ratified the Biomedicine Convention in 2011 (Chart of signatures and ratifications of Treaty 164,2021$).{ }^{10}$ The Biomedicine Convention contains the prohibition of inheritable genetic modifications. Article 13 of the Biomedicine Convention provides that "an intervention seeking to modify the human genome may only be undertaken for preventive, diagnostic or therapeutic purposes and only if its aim is not to introduce any modification into the genome of any descendants". The basis for the prohibition of inheritable genetic modification can be found in the Explanatory Report to the Biomedicine Convention: "whilst developments in this field may lead to great benefits for humanity, misuse of these developments may endanger not only the individual but the species itself" ${ }^{\prime 1}$ Article 18 (2) of the Biomedicine Convention is also relevant in relation to cloning and genetic modification since it prohibits the creation of human embryos exclusively for research purposes. Gene editing of the embryo through the CRISPR technique is most efficient before the first cell division, directly or after fertilization, since the later-stage embryos are prone to mosaicism, which implies a developing embryo that has both edited and unedited cells (Winblad et al., 2017: p. 399). Therefore, extra embryos left from the in vitro fertilization procedure (IVF) do not represent the best choice for gene editing.

The Biomedicine Convention does not contain provisions related to the prohibition of reproductive cloning. Just one year later, the Council of Europe adopted the Additional Protocol to the Biomedicine Convention on the Prohibition

9 Convention for the Protection of Human Rights and Dignity of the Human Being with regard to the Application of Biology and Medicine: Convention on Human Rights and Biomedicine, Oviedo, 4.IV.1997, European Treaty Series - No. 164.

10 Chart of signatures and ratifications of Treaty 164, Council of Europe Treaty Office, Status as of 14/07/2021, available at: https://www.coe.int/en/web/conventions/full-list/-/conventions/treaty/164/ signatures?module=signatures-by-treaty\&treatynum=164. Accessed on 14.07.2021.

11 Explanatory Report to the Convention for the Protection of Human Rights and Dignity of the Human Being with regard to the Application of Biology and Medicine: Convention on Human Rights and Biomedicine - Explanatory Report to the Convention on Human Rights and Biomedicine. Oviedo, 4.IV.1997, European Treaty Series - No. 164, par. 89. 
of Cloning Human Beings, especially devoted to this issue (hereinafter: Protocol on Cloning). ${ }^{12}$ The Protocol on Cloning has been ratified by 24 Council of Europe member states at the moment, and the Republic of Serbia is not among them (Chart of signatures and ratifications of Treaty 168, 2021). ${ }^{13}$ The Protocol on Cloning prohibits any intervention seeking to create a human being genetically identical to another human being, whether living or dead. The term human being "genetically identical" to another human being is defined as a human being sharing with another the same nuclear gene set. Therefore, the term cloning is not used, making the provision determined by the result, regardless of the used technique. The Protocol on Cloning is directed exclusively at reproductive cloning. In this regard, it is also necessary to distinguish two relevant situations, namely cloning of cells and tissue, which is considered an ethically more acceptable and valuable technique, and cloning of undifferentiated cells of embryonic origin. In the case of cloning of undifferentiated cells, their creation for research purposes exclusively is prohibited by Article 18 of the Biomedicine Convention. The use of embryonic cells is left for regulation in the future protocol on embryo protection. ${ }^{14}$ However, this protocol was never adopted. Therapeutic cloning is considered to be an ethically sensitive issue since the cloning of undifferentiated cells implies the destruction of embryos. On the other hand, extra embryos created in the course of IVF which are not implanted, are destined for destruction, although not a deliberate one.

At the EU level, the EU Charter of Fundamental Rights of 2000 (hereinafter: the EU Charter) contains a unique provision devoted to the prohibition of reproductive cloning of human beings in Article 3, Paragraph $2 .{ }^{15}$ The EU Charter prohibits only reproductive cloning. It neither authorises nor prohibits other forms of cloning. Reproductive cloning is prohibited within the right to the integrity of the person. It may be argued that the connection between the ban on cloning and the protection of physical and mental integrity is not entirely clear. Namely, if a person's genetic material uniqueness was endangered by cloning, this issue could

12 Council of Europe (1998). Additional Protocol to the Convention for the Protection of Human Rights and Dignity of the Human Being with regard to the Application of Biology and Medicine, on the Prohibition of Cloning Human Beings. European Treaty Series. No. 168. Paris, 12.I.1998.

13 Chart of signatures and ratifications of Treaty 168, Council of Europe Treaty Office, Status as of 14/07/2021, available at: https://www.coe.int/en/web/conventions/full-list/-/conventions/treaty/168/ signatures?module=signatures-by-treaty\&treatynum $=168$, accessed on 14.07.2021.

14 Explanatory Report to the Additional Protocol to the Convention for the Protection of Human Rights and Dignity of the Human Being with regard to the Application of Biology and Medicine, on the Prohibition of Cloning Human Beings, Paris, 12.I.1998, European Treaty Series - No. 168, par. 2.

15 Charter of Fundamental Rights of the European Union. Official Journal of the European Union. C 83/391, 30.3.2010. 
be easily resolved with the consent of that person. If the ban concerns the protection of the integrity of a future child, it is not clear how the clone can be reduced to serving other people's purposes (which is often stated as an argument), instead of being valued as a human being with his or her own value (S. Michalowski, 2004: 306). There is also the view that reproductive cloning does not offend the dignity of the clone, but the very act of creating such a human being would be contrary to human dignity (Labrou, 2012: 67-68). In any case, it should be borne in mind that the integrity of the clone is questionable in relation to its physical health, given that it is well-known that clones can suffer from various disorders. A recent experiment on monkeys supports this fact, since the cloned monkeys were short-lived. Here, the integrity of the clone is protected in advance by preventing the creation of the clone. This would, however, mean that if technology advances, making cloning safe for the clone, the prohibition would be unnecessary. Reproductive cloning of humans is difficult to encompass within existing human rights. The Explanatory Report to the Protocol on Cloning states that intentional cloning of people "poses a threat to human identity". ${ }^{16}$ A person who is the owner of genetic material ("original") could exclude the right to his or her unique genetic identity by the autonomy of the will, agreeing to create a clone from his or her genetic material. However, the clone would not have this possibility since its will is unknown, and respect for this right of the clone was possible only before clone creation. The prohibition of reproductive cloning might be situated somewhere between the right to human identity and the right to human integrity.

A paternalistic approach in this area is certainly present since it is also assumed that reproductive cloning represents an insult to the broad notion of human dignity (which is also used in order to achieve greater consensus) and not concretely to individual rights. Recourse to paternalism in the case of unknown consequences of a technology is completely understandable, having in mind that the prohibition on cloning is not firmly situated in any of the well-established human rights.

It seems that the EU Charter might also deal with genetic modifications within the right to the integrity of the person. Although the meaning of this provision is puzzling, Article 3 of the EU charter states that "in the fields of medicine and biology, the following must be respected, in particular:... the prohibition of eugenic practices, in particular, those aiming at the selection of persons". The words "in particular" are used two times. Therefore, it is possible that some other prohibited practices in the fields of medicine and biology are also included

16 Explanatory Report to the Additional Protocol to the Convention for the Protection of Human Rights and Dignity of the Human Being with regard to the Application of Biology and Medicine, on the Prohibition of Cloning Human Beings, par 3. 
(other than the practices explicitly stated), and that some eugenic practices not aimed at the selection of persons might also be included by the provision. In addition, there is no uniform definition of eugenic practices. Judging by the Explanations relating to the EU Charter, it seems that the provision does not have any special, new purpose in relation to biology and medicine. It states that the reference to eugenic practices "relates to possible situations in which selection programmes are organised and implemented, involving campaigns for sterilisation, forced pregnancy, compulsory ethnic marriage among others, all acts deemed to be international crimes in the Statute of the International Criminal Court adopted in Rome on 17 July 1998 (see its Article 7(1)(g))." ${ }^{17}$ This kind of eugenic practice is probably closer to the prohibition of torture and other cruel, inhuman, and degrading treatment or punishment. However, if the provision is also aimed at the prohibition of inheritable genetic modifications as a form of "not particular" eugenic practice, it could be tied to the prohibition of the integrity of the human species as such, as a collective right, or the physical or mental integrity of the future person or persons affected by the modification. In addition, the creation of chimeras and hybrids is not mentioned in Article 3 of the EU Charter, although they are also strongly related to the fields of medicine and biology.

The Directive on the legal protection of biotechnological inventions states that interventions into the human germline and cloning of human beings offend the ordre public and morality. ${ }^{18}$ Cloning of human beings, processes for modifying the germline genetic identity of human beings, and processes for modifying the genetic identity of animals that are likely to cause them suffering without any substantial medical benefit, and animals resulting from such processes as well, are considered to be unpatentable. ${ }^{19}$ In addition, the rules that govern clinical trials reflect a negative attitude toward inheritable genetic modifications, since "no gene therapy clinical trials may be carried out which results in modifications to the subject's germline genetic identity." ${ }^{20}$ However, all the relevant provisions did not stop MRT in Greece, for example, and this issue did not attract any official response from the EU.

17 Explanations Relating to the Charter of Fundamental Rights, Official Journal of the European Union, C 303/18, 14.12.2007, p. 18.

18 Directive 98/44/EC of the European Parliament and of the Council of 6 July 1998 on the legal protection of biotechnological inventions, Official Journal of the European Communities, 30.7.1998, L 213/13, Preamble, par. 40.

19 Ibid., Article 6 (2).

20 Regulation EU No 536/2014 of the European Parliament and of the Council of 16 April 2014 on clinical trials on medicinal products for human use, and repealing Directive 2001/20/EC, Official Journal of the European Union, L 158/1, 27.5.2014, Article 90. 


\section{Serbian criminal law}

In countries where reproductive cloning of humans is prohibited, this prohibition is sometimes explicitly guaranteed by the constitution, but usually, it represents a criminal offence, with criminal sanctions ranging from fines to imprisonment for up to 30 years (Škorić, 2007:1247). Some countries explicitly forbid the creation of clonal embryos, while others allow the creation of such embryos for research purposes, although the implantation of such embryos is forbidden. In the United States, for example, there is no federal law prohibiting reproductive cloning of humans. Federal laws and regulations only address funding. However, at the state level, some laws directly prohibit reproductive cloning for any purpose, some prevent cloned embryo implantation for childbirth (therefore allowing research on cloned embryos), and some expressly prohibit state funding of human cloning for any purpose (Jardine, 2018).

The Constitution of the Republic of Serbia prohibits cloning of human beings within the right to life in Article 24 (3). ${ }^{21}$ However, the link between the right to life and the prohibition of cloning is not clear. The prohibition of reproductive cloning might even represent the prohibition of the right to life of the future cloned human being. Therefore, this prohibition would be better situated within Article 25, which protects the physical and mental integrity of the person and prohibits medical and other experiments without free consent since, for the time being, the health of the cloned person would be significantly affected. Alternatively, the best solution would be the placement of the prohibition within the right to dignity and free development of individuals in Article 23 of the Constitution of the Republic of Serbia (Simović, 2008:332). Of course, there is also an issue of constitutionalization of this particular practice, and not inheritable genetic modifications, which can cause consequences for the entire human species, or the creation of chimeras or hybrids (or a wide range of other specific practices from non-related fields).

The Criminal Code of Serbia (CC) regulates the prohibition of cloning in Article 252(2), within the chapter directed at criminal offences against human health. ${ }^{22}$ This is a better-suited placement than, for example, within the chapter directed at criminal offences against life and limb. Integrity of the person from which the genetic material derives from, is significantly less affected for the time being, than the general health of the clone. The criminal offence of illegal con-

21 Constitution of the Republic of Serbia ("Official Gazette of the RS”, No. 98/06).

22 Criminal Code, Official Gazette of the Republic of Serbia, no. 85/05, 88/05 - corrected, 107/05 corrected, 72/09, 111/09, 121/09, 104/13, 108/14, 94/16 and 35/19. 
ducting of medical experiments and testing of drugs from Article 252 of the CC contains three related criminal offences: conduct of medical or similar experiments on humans contrary to regulations, cloning of human beings and clinical testing of drugs contrary to regulations (Stojanović, 2021:853). Article 252 (1) of the CC states: "whoever contrary to regulations conducts medical or similar experiments on humans, shall be punished by imprisonment of three months to five years", and in Article 252 (2) "the penalty specified in paragraph 1 of this Article shall be imposed also on whoever clones human beings or conducts experiments to that purpose". Therefore, besides the prohibition of reproductive cloning, the act of commission is also directed at the preparation of the act. Given this formulation, it appears that there is no clear distinction between reproductive and therapeutic cloning and that therapeutic cloning could also be considered prohibited (Kostić, Ranaldi, 2019: 327). The Law on biomedically assisted reproduction is also relevant. In the process of biomedically assisted fertilisation, it is prohibited to enable the creation of embryos with a same-sex hereditary basis or embryos that have an identical hereditary basis as another living or dead person (cloning)“" ${ }^{23}$ This provision also seems to be directed at therapeutic cloning, since the term of creation is used, and not the term of implantation.

The Law on biomedically assisted reproduction also prohibits the creation of embryos for any other purpose than biomedically assisted reproduction, which is in line with the Biomedicine Convention. ${ }^{24}$ Extra embryos created in the course of biomedically assisted reproduction can be used for research purposes only with the consent of both partners. ${ }^{25}$ Extra embryos left from the in vitro fertilization procedure (IVF) are not best suited for gene editing. However, it is possible that partners use "enhanced" embryos primarily for the purpose of biomedically assisted reproduction.

When it comes to inheritable genetic modifications, the $\mathrm{CC}$ does not regulate this particular practice. However, Article 252 (1) of the CC might encompass it. A medical experiment understood in the broadest sense involves the use of a drug or procedure that has not been broadly accepted or has not been used by a significant number of physicians (Radišić, 2008: 255). The Law on biomedically assisted reproduction prohibits different practices which can relate to the term inheritable genetic modifications (including MRT), as well as the creation of hybrids and chimeras. ${ }^{26}$ However, the Law on biomedically assisted reproduction does not recognize these practices as a criminal offence. There is only the possibility of fines

23 Law on biomedically assisted reproduction, no. 40/2017 and 113/2017-other law, Article 49 (5).

24 Ibid., Article 49 (13).

25 Ibid., Article 53.

26 Ibid., Article $49(6-11,14,19)$. 
in the case of the creation of embryos for other purposes than biomedically assisted reproduction, and the possibility of revoking the licence for undertaking activities related to biomedically assisted reproduction. ${ }^{27}$ The Law on Medicines and Medical Devices also prohibits clinical trials, which might result in modifications to the subject's germline genetic identity. ${ }^{28}$ In addition, the Law on patents, in line with EU regulations, declares unpatentable: cloning of human beings, processes for modifying the germline genetic identity of human beings, and for modifying the genetic identity of animals that are likely to cause them suffering without any substantial medical benefit, and animals resulting from such processes. ${ }^{29}$

Many European countries do not have a specific prohibition on germline alterations in humans. However, EU law prohibits patents for germline alteration processes and no gene therapy clinical trials that result in modifications to the subject's germline genetic identity may be carried out. In some countries, however, they do represent criminal offences, but with significant variations. For example, besides the prohibition of cloning and the prohibition related to mixing human sex cells with animal sex cells, Article 108 of the Criminal Code of the Republic of Croatia prohibits human genome changes (within the chapter of crimes against humanity and human dignity). ${ }^{30}$ The imposed sanction is milder than in the case of cloning and mixing human sex cells with animal sex cells (imprisonment from one to ten years). Namely, "whoever carries out an intervention seeking to modify the human genome for purposes other than preventive, diagnostic or therapeutic, or does so for preventive, diagnostic or therapeutic purposes, but with the aim of introducing modifications into the genome of a patient's descendent shall be punished by imprisonment from six months to five years". In Slovenian Criminal Code, reproductive cloning of human beings, along with the prohibition of creation of human embryos for research, industrial or commercial purposes, is prohibited in the group of crimes against humanity, with the prescribed penalty of imprisonment between ten and fifteen years. ${ }^{31}$ However, modification of the human genome is regulated within the chapter devoted to criminal offences against public health, with the prescribed penalty of imprisonment for not

27 Ibid., Article 67 and 16.

28 Law on medicines and medical devices, Official Gazette of the Republic of Serbia, no. 30/2010; 107/2012-other law and 113/2017-other law).

29 Patent Law, Official Gazette of the Republic of Serbia, no. 99/11, 113/2017-other law 95/2018, 66/2019., Article 9.

30 Criminal Code of the Republic of Croatia, Official Gazette of the Republic of Croatia, no. 125/2011, 144/2012, 56/2015, 61/2015, 101/2017 and 118/2018

31 Kaznenski zakonik, „Uradni list RS“, broj 50-2012-prečišćen tekst, 6/2016, 54/2012, 38/2016 i 27/2017., Article 114 (2). 
more than five years. ${ }^{32}$ The Criminal Code of Finland also regulates all three situations, prescribing significantly lenient penalties. ${ }^{33}$ The French Criminal Code regulates "crimes in relation to eugenics and reproductive cloning", and cloning is defined as a procedure designed to cause the birth of a child genetically identical to another person, whether living or deceased, and is punishable by thirty years of criminal imprisonment and a fine of $€ 7,500,000 .{ }^{34}$ The same penalty is prescribed for "implementing any eugenic practice aimed at organising the selection of persons" ${ }^{35}$ However, this offence seems more related to crimes against humanity than to the prohibition of inheritable genetic modifications. ${ }^{36}$ The German Embryo Protection Act prohibits the use of a human germ cell with artificially altered genetic information for fertilisation, but also artificial altering of the genetic information of a human germline cell (therefore, without fertilisation), with the prescribed penalty of imprisonment of up to five years or a fine. ${ }^{37}$ The same penalty is prescribed for cloning, as well as for the creation of chimeras and hybrids. ${ }^{38}$ Some countries allow inheritable genetic modifications in the case of MRT, like the United Kingdom (Vogel, 2016). For example, in the United States, there is no law prohibiting inheritable genetic modifications, but, like in the case of cloning, it imposes limits on funding for research involving embryos in general and genome editing of embryos in particular (Yotova, 2017:45).

\section{Concluding observations}

Unlike interventions on the human genome, reproductive cloning is not that promising in relation to possible therapeutic functions. A possible therapeutic

32 Ibid., Article 181 (5).

33 Criminal Code of Finland, 39/1889 amendments up to 766/2015 included, translation from Finnish, available at: https://www.finlex.fi/en/laki/kaannokset/1889/en18890039.pdf, 15.07.2021.

34 Criminal Code of the French Republic (as of 2005), translation from French, available at: https:// www.legislationline.org/download/id/3316/file/France_Criminal\%20Code\%20updated\%20on\%20 12-10-2005.pdf, 14.07.2021, Article 214 (2).

35 Ibid., Article 214 (1).

36 Imposed penalty appears severe for both crimes, however French law gives judges large discretion in sentencing, Article 132 (17-20) of the Criminal Code of the French Republic.

37 The Embryo Protection Act, Federal Law Gazette, Part I, No. 69, Bonn, 19th December 1990, page 2746, (Gesetz zum Schutz von Embryonen of 13th December 1990), translation from German, available at: https://www.rki.de/SharedDocs/Gesetzestexte/Embryonenschutzgesetz_englisch. pdf?_blob=publicationFile, 14.07.2021, Section 5 (1-2).

38 The Embryo Protection Act also regulates improper use of reproduction technology, improper use of human embryos, forbidden sex selection and unauthorized fertilization, embryo transfer and artificial fertilization after death, prescribing more lenient penalties. 
function of reproductive cloning would be to allow some couples, or even individuals, to have a child to which they are genetically related. Inheritable genetic modifications, however, can represent a cure for a very wide range of diseases and can be an instrument of human enhancement. Most importantly, the social dangers or harms arising from inheritable genetic modifications seem even greater than in the case of reproductive cloning. Inheritable genetic modifications of humans have the potential to affect the whole of humanity, including future generations. For the time being, they are not safe, and off-targeted mutations can have pathogenic consequences. Even if they eventually become completely safe, the issue of the distinction between enhancement and therapy will be difficult to draw, and the effects on future generations will still be uncertain. International regulation of inheritable genetic modifications at the universal level is not likely to happen, having in mind the failed attempt on legally binding prohibition of reproductive cloning. However, at the European level, the legally binding Biomedicine Convention succeeded in prohibiting inheritable genetic modifications, while reproductive cloning is regulated by the Protocol on Cloning. The EU Charter seems rather confusing on the matter. It prohibits reproductive cloning, but when it comes to inheritable genetic modifications, the situation is less clear. International law can prove to be suitable when it comes to deciding on which new technologies should be prohibited, restricted or allowed since the consequences can affect the entire human species, and having in mind the so-called phenomenon of reproductive tourism. However, there are always countries that might wish to accommodate potential commercial benefits.

The prohibition of cloning found its place in the Constitution of the Republic of Serbia and in the $\mathrm{CC}$ as well. However, inheritable genetic modifications, as well as the artificial creation of chimeras and hybrids, could represent criminal offences only within the prohibition of medical or similar experiments on humans in Article 252 (1) of the CC. The explicit prohibition of reproductive cloning might lead to the conclusion that this technique is more dangerous than inheritable genetic modifications of humans.

A possible solution involves encompassing the prohibition of inheritable genetic modifications, as well as the artificial creation of chimeras and hybrids within the CC. Alternatively, the Law on biomedically assisted reproduction can prescribe all three as criminal offences, while the general prohibition of medical or similar experiments on humans will remain in the CC. However, this would not be the best solution, considering the constitutionalization of the prohibition of reproductive cloning. When it comes to penalties, heavier penalties in the case of reproductive cloning and the creation of chimeras and hybrids than in the case of inheritable genetic modifications do not seem justified (Criminal Code of the 
Republic of Croatia). Although these two might seem less publicly acceptable at first glance, inheritable genetic modifications are equally, if not even more dangerous. The penalty prescribed for the criminal offence of medical or similar experiments on humans for all three potential criminal offences seems more suitable for the time being.

\section{References}

- Arsanjani, M. H. (2006) Negotiating the UN Declaration on Human Cloning. American Journal of International Law, 100(1), pp. 164-179. https://doi. org/10.2307/3518835

- Center for Genetics and Society, Human Genetic Modification, https://www. geneticsandsociety.org/topics/human-genetic-modification

- Clados, M. S. (2012) Bioethics in International Law: An Analysis of the Intertwining of Bioethical and Legal Discourses. München: Inaugural-Dissertation zur Erlangung des Doktorgrades der Philosophie an der Ludwig-Maximilians-Universität.

- Đukanović, A. (2019) New Eugenics in Light of International Human Rights Protection. The Review of International Affairs, LXX (1175), pp. 5-22.

- European Group on Ethics in Science and New Technologies (2019) Opinion on Ethics on Geneome Editing, Opinion no. 32, European Commission: Brussels, available at: https://ec.europa.eu/info/sites/default/files/research_and_innovation/ege/ege_ethics_of_genome_editing-opinion_publication.pdf

- German Reference Centre for Ethics in the Life Sciences (2019) In Focus: Somatic Gene Therapy. available at: http://www.drze.de/in-focus/somaticgene-therapy

- Ghose, T. (September 2016) World's First ,3-Parent' Baby Born: Is It Ethical?, Live Science. available at: https://www.livescience.com/56299-three-personbaby-created.html

- Hunter, C. (2009) Chimeras The Ethics of Creating Human-Animal Interspecifics. Ludwig-Maximilians-Universität: Munich, available at: https://edoc. ub.uni-muenchen.de/10022/1/Huther_Constanze.pdf (12.07.2020).

- Jardine, J.J. (2018) The Law and Human Cloning, Knobbe Martens, available at: https://www.knobbe.com/news/2018/06/law-and-human-cloning

- Jarrell, C. (2006) No Worldwide Consensus: The United Nations Declaration on Human Cloning“. The Georgia Journal of International and Comparative Law, 35 (1), pp. 205-232.

- Kostić, J., Ranaldi, V. (2019) Criminal Sanctions For Cloning Human Beings. In: Ivana Stevanović Nikola Vujičić (eds.) National And Comparative Criminal 
Legislation Penal Law and Medicine, Belgrade: Institute of Criminological and Sociological Research Serbia.

- Kuchler, H. (13 March 2019) Scientists plead for moratorium after designer babies outcry, Developers of Crispr technique for genome editing also call for halt to experiments on hereditary genes. Financial Times, available at: https:// www.ft.com/content/468a1f16-45c9-11e9-a965-23d669740bfb

- Labrou, C. (2012) The Use of Therapeutic Cloning in Transplantations: An Aristotelian Perspective. UCL Journal of Law and Jurisprudence, 1(1), pp. 63-87.

- -Ledford, H. (19 June 2019) CRISPR babies: when will the world be ready? Nature, available at: https://www.nature.com/articles/d41586-019-01906-z

- Liu, Z., Cai, Y. at al. (2018) Cloning of Macaque Monkeys by Somatic Cell Nuclear Transfer", Cell, 172(4), pp. 881-887 https://doi.org/10.1016/j.cell.2018. 01.020, pp. 881-887.

- Michalowski, S. (2004) Health Care Law, in: Peers Steve, Ward Angela (eds.), The European Union Charter of Fundamental Rights -Politics, Law and Policy. Hart Publishing: Oxford, Portland.

- Mujović-Zornić, H. (2007), Izazovi biomedicine: kloniranje i šta to znači za pacijentova prava, U: Rašević, M. i Mršević, Z. (urs.) Pomeramo granice. Beograd: Institut društvenih nauka.

- National Research Council (2002) Scientific and Medical Aspects of Human Reproductive Cloning, Washington, D.C: National Academy Press, available at: https://www.ncbi.nlm.nih.gov/books/NBK223962/pdf/Bookshelf_ NBK223962.pdf

- Navratyil, Z. (2013) Legal and Ethical Aspects of Human Reproductive Cloning. Acta Juridica Hungarica, 54(1), pp. 106-117. https://doi.org/10.1556/ ajur.54.2013.1.8

- Newson, A. J., Wrigley, A. (2017) Is Mitochondrial Donation Germ-Line Gene Therapy? Classifications and Ethical Implications. Bioethics, 31(1), doi: 10.1111/bioe.12312, pp. 55-67.

- Nuffield Council on Bioethics (2016) Genome editing, available at: https:// www.nuffieldbioethics.org/wp-content/uploads/Genome-editing-an-ethical review.pdf

- Ong, S. (2018) Singapore could become the second country to legalize mitochondrial replacement therapy. Science, available at: https://www.sciencemag. org/news/2018/06/singapore-could-become-second-country-legalize-mitochondrial-replacement-therapy

- Powell, R. (2015) In Genes We Trust: Germline Engineering, Eugenics, and the Future of the Human Genome. Journal of Medicine and Philosophy, 40(6), pp. 669-695.Doi: 10.1093/jmp/jhv025. 
- Radišić, J. (2008) Medicinsko pravo. Beograd: Nomos.

- Sigal, S. (2019) A celebrity biohacker who sells DIY gene-editing kits is under investigation, Vox, available at: https://www.vox.com/future-perfect/2019/5/19/18629771/biohacking-josiah-zayner-genetic-engineering-crispr

- Simović, D. (2008) Ljudska prava u Ustavu Srbije od 2006. - kritička analiza. U: Zoran Radivojević (ur.) Ustavne i međunarodnopravne garancije ljudskih prava. Niš: Pravni fakultet u Nišu, Centar za publikacije

- Stojanović, Z. (2021) Komentar Krivičnog zakonika. Beograd: Službeni Glasnik

- Strong, C. (2005) Reproductive Cloning Combined with Genetic Modification. Journal of Medical Ethics, 31(11), pp. 654-658.

- Škorić, M. (2007) Pravna regulacija reproduktivnog i terapeutskog kloniranja na međunarodnoj i nacionalnoj razini. Zbornik Pravnog fakulteta Sveučilišta Rijeci, 28(2), str. 1239-1267.

- Thomson, H. (11 April 2019) First 3-parent baby born in clinical trial to treat infertility.New Scientist, available at: https://www.newscientist.com/ article/2199441-first-3- parent-baby-born-in-clinical-trial-to-treatinfertility/\#ixzz6yPfQHY3a

- Van Beers, B. (2020) Rewriting the human genome, rewriting human rights law? Human rights, human dignity, and human germline modification in the CRISPR era. Journal of Law and the Biosciences, 7(1), pp. 1-36 https://doi. org/10.1093/jlb/lsaa006

- Viswanathan, R. (Jul 28, 2018) 3 biological parents, 1 child, and an international controversy, Vox, available at: https://www.vox.com/2018/7/24/ 17596354/mitochondrial-replacement-therapy-three-parent-baby-controversy

- Vogel, G. (2016) United Kingdom gives green light for mitochondrial replacement technique, Science, available at: https://www.sciencemag.org/ news/2016/12/united-kingdom-gives-green-light-mitochondrial-replacementtechnique

- Winblad, N. Lanner, F. (2017) At the heart of gene edits in human embryos. Nature, 548, pp. 398-400. https://doi.org/10.1038/nature23533

- Xinhuanet (30.12.2019) He Jiankui and other three defendants were prosecuted for criminal responsibility in the first instance of ,gene-edited babies” case, available at: http://www.xinhuanet.com/legal/2019-12/30/c_1125403802.htm

- Yotova, R. (2017) Report on regulation -the Regulation of Genome Editing and Human Reproduction Under International Law, EU Law and Comparative Law, available at: https:/www.nuffieldbioethics.org/wp-content/uploads/ Report-regulation-GEHR-for-web.pdf, 14.07.2021 